\title{
Comparison of the Technological Application Potential of Functional Ingredients for the Meat Industry Based upon a Novel Fast Screening Tool
}

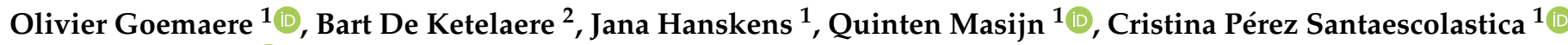 \\ and Ilse Fraeye ${ }^{1, * \mathbb{D}}$ \\ 1 Research Group for Technology and Quality of Animal Products, Department of Microbial and Molecular \\ Systems, Leuven Food Science and Nutrition Research Centre (LFoRCe), KU Leuven Ghent Technology \\ Campus, B-9000 Gent, Belgium; olivier.goemaere@kuleuven.be (O.G.); jana.hanskens@kuleuven.be (J.H.); \\ quinten.masijn@kuleuven.be (Q.M.); cristina.perezsantaescolastica@kuleuven.be (C.P.S.) \\ 2 KU Leuven, Faculty of Bioscience Engineering, BIOSYST-MeBioS, Kasteelpark Arenberg 30, \\ B-3001 Leuven, Belgium; bart.deketelaere@kuleuven.be \\ * Correspondence: ilse.fraeye@kuleuven.be; Tel.: +32-9-331-6617
}

Citation: Goemaere, O.; De Ketelaere, B.; Hanskens, J.; Masijn, Q.; Pérez Santaescolastica, C.; Fraeye, I Comparison of the Technological Application Potential of Functional Ingredients for the Meat Industry Based upon a Novel Fast Screening Tool. Foods 2021, 10, 2078. https:// doi.org/10.3390/foods10092078

Academic Editors: Inmaculada Franco Matilla and Elena Falqué López

Received: 10 August 2021

Accepted: 31 August 2021

Published: 2 September 2021

Publisher's Note: MDPI stays neutral with regard to jurisdictional claims in published maps and institutional affiliations.

Copyright: (c) 2021 by the authors. Licensee MDPI, Basel, Switzerland. This article is an open access article distributed under the terms and conditions of the Creative Commons Attribution (CC BY) license (https:// creativecommons.org/licenses/by/ $4.0 /)$.

\begin{abstract}
The application potential of functional ingredients for the meat industry is often assessed through different measuring tools, thereby making comparisons difficult. The aim of this study was to create valuable information about the performance of functional ingredients based upon standardized and comparable data gathered through a newly developed screening tool. Therefore, 25 ingredients, selected from different techno-functional classes, were characterized at 2 different dosages by means of the screening methodology. The tool itself consisted of a lean meat model and fatty liver-based system, representative of the finely minced and/or emulsified charcuterie market. A total of 23 different parameters were measured through both model systems, providing information concerning water and fat binding capacity, emulsification, and texture and structure formation. Through cluster analysis, the ingredients were assigned to groups, each with their own specific properties. The screening tool provided good descriptive and distinctive power concerning ingredient functionalities and offers the industry a clear overview of their application characteristics.
\end{abstract}

Keywords: ingredient functionality; meat model systems; standardized methodology; cluster analysis

\section{Introduction}

Processed meat products often contain so-called techno-functional ingredients that are added to improve product quality, reduce formulation costs, satisfy consumer needs (texture, flavor, appearance, etc.), and to keep up with current market trends, such as clean label, fat reduction, and salt reduction. Balestra and Petracci [1] indicated that these ingredients can be divided into those that influence the functionality of the myofibrillar proteins (such as salt and phosphate) and those that form an extra system to increase water and fat binding and/or optimize product texture. This publication deals with the latter group, which can be further divided into several product classes, including starches, plant and animal proteins, dietary fibers (soluble and insoluble fibers, gums, ... ), and emulsifiers sensu stricto. In literature and through market survey, a lot of useful and scientific knowledge can be found with regard to their application in meat products. However, this information is subject to two drawbacks.

Firstly, ingredient manufactures often rely on water-based model systems to describe the characteristics of their products. Yet, it is well-known that ingredients often behave differently in a watery environment compared to a meat matrix. The importance of a meat matrix to measure ingredient functionality was described by Balestra and Petracci [1]. A 
food matrix is a much more complex medium, where multiple interactions between ingredients and other components (i.e., salts, lipids, and proteins) may occur, thus modifying the performance of the functional ingredient [2].

Many authors [1,3-13] researched and reviewed the potential of numerous technofunctional ingredients in different meat products. Despite good information available in these studies, this knowledge is subject to the second drawback. Standardized comparison between ingredients for specific quality characteristics such as water binding or texture development is difficult because these surveys were conducted on different meat matrices (differences in meat product class, composition of recipes, and processing conditions) and different analyzing techniques were applied. The development of a well-balanced, standardized, elementary meat matrix could therefore provide a good screening environment for the potential of functional ingredients for the meat industry, resulting in uniform and easily comparable scientific data.

Furthermore, a comprehensive literature study revealed that functional ingredients often contribute to similar quality characteristics (water and fat binding, structure formation, texture improvement) in meat products, despite their difference in nature, origin, or product class. Therefore, classification of ingredients (at specific dosages) based upon similar behavior rather than product class could be more beneficial or practical for the meat industry. As mentioned before, a standardized and uniform measuring tool is hereby of great value. Therefore, the goal of this study is to gather key information concerning the characteristics of 25 techno-functional ingredients, each applied at two dosages in a meat matrix based upon a newly developed screening tool. The obtained standardized and scientifically collected data are statistically processed to cluster ingredient $x$ dosage combinations in groups exerting similar performances. This will lead to better insights and understanding of their functionalities, and thus, better estimation of the use of certain ingredient $x$ dosage combinations in specific meat applications.

\section{Materials and Methods}

\subsection{Experimental Setup}

A lean meat model (LMM) and fatty liver-based model system (FLM) were developed and validated to serve as a standardized screening tool for the measurement of functional ingredient characteristics. They represent the wide range of both lean (cooked ham) and fatty heated meat products available in the market. Altogether, 23 different parameters (see following sections) were measured through the model systems.

In both LMM and FLM, a total of 25 ingredients were tested. The choice of ingredients was based upon a short inquiry of the Flemish meat industry and was mainly directed by their common practice. Ingredients were derived from different functional classes and fixed low (LD) and high dosage (HD) levels were defined for each class, based on ingredient product sheets and literature (Table 1). The LD of each ingredient class corresponds to the minimum concentration needed to improve product quality to some extent. The ingredient dosages were calculated relative to the total mass of meat raw materials (Longissimus dorsi muscle for LMM; liver and back fat for FLM) and water.

To match the scientific goals to the available experimental material and time, the experiments were optimized in such a way that replication was maximized for each treatment (i.e., ingredient $x$ dosage combination), and this was the case for both model systems, taking into account the different ingredient classes that were considered (Table 1). In addition, blanks (4 replicates) of both LMM and FLM lacking any ingredient were included as a reference treatment. A total of 104 experimental runs, including the 4 blanks, were performed throughout the study, and this was applied to both the LMM and FLM model systems. 
Table 1. Overview of screened ingredients including product names, classes, and tested dosages within each product class (low and high dosage, LD and HD, respectively). Abbreviations used: к (Kappa), ı (Iota).

\begin{tabular}{|c|c|}
\hline Product Class/Tested Dosage (LD-HD) & Product Name \\
\hline $\begin{array}{c}\text { Animal protein } \\
1-2 \%\end{array}$ & $\begin{array}{c}\text { Collagen } \\
\text { Gelatin } 120 \text { bloom } \\
\text { Gelatin } 200 \text { bloom } \\
\text { Blood plasma } \\
\text { Globin } \\
\text { Caseinate }\end{array}$ \\
\hline $\begin{array}{c}\text { Vegetable protein } \\
\qquad 1-2 \%\end{array}$ & $\begin{array}{l}\text { Pea protein } \\
\text { Rice protein } \\
\text { Soy isolate }\end{array}$ \\
\hline $\begin{array}{l}\text { Starch } \\
1.5-3 \%\end{array}$ & $\begin{array}{l}\text { Potato starch } \\
\text { Rice starch } \\
\text { Wheat starch }\end{array}$ \\
\hline $\begin{array}{c}\text { (in)Soluble fiber } \\
1-3 \%\end{array}$ & $\begin{array}{c}\text { Insoluble citric fiber } \\
\text { Citric fiber } \\
\text { Bamboo fiber/psyllium } \\
\text { Pea fiber }\end{array}$ \\
\hline $\begin{array}{l}\text { Gum } \\
0.5-1 \%\end{array}$ & $\begin{array}{c}\text { Guar gum } \\
\text { Xanthan gum } \\
\text { Locust bean gum } \\
\text { Alginate } \\
\text { K-carrageenan } \\
\text { K-l-carrageenan } \\
\text { l-carrageenan }\end{array}$ \\
\hline $\begin{array}{c}\text { Emulsifier sensu stricto } \\
0.3-1 \%\end{array}$ & $\begin{array}{l}\text { Citric acid esters of fatty acids } \\
\text { Sucrose esters of fatty acids }\end{array}$ \\
\hline
\end{tabular}

\subsection{Manufacturing of Lean Meat and Fatty Liver-Based Model Systems}

LMM and FLM model systems were prepared in the pilot plant of the research group 'Technology and Quality of Animal Products' (KU Leuven Ghent Technology Campus, Gent, Belgium). Raw materials (pork L. dorsi muscle, pork liver, and pork back fat) were purchased from a local supplier. The entire experiment was performed using a single homogeneous batch of each respective raw material. Back fat was cut into small cubes, and L. dorsi muscle and liver were ground through an $8 \mathrm{~mm}$ plate. All raw materials were each mixed thoroughly to obtain a large uniform batch of each raw material, packed as smaller portions into plastic bags and frozen $\left(-18{ }^{\circ} \mathrm{C}\right)$ until use. The day before preparation of the specific model systems, raw materials were thawed overnight in a refrigerator at $4{ }^{\circ} \mathrm{C}$. This approach allowed us to study only the impact of the ingredients without interference of potential variability in raw material characteristics.

LMM was composed of L. dorsi muscle $(40 \mathrm{~g} / 100 \mathrm{~g})$ and ice-water $(60 \mathrm{~g} / 100 \mathrm{~g})$, in which nitrite curing salt $(1.6 \mathrm{~g} / 100 \mathrm{~g})$ and tetrasodium pyrophosphate $(0.2 \mathrm{~g} / 100 \mathrm{~g})$ were dissolved in advance. Auxiliary ingredients were calculated relative to the total mass of meat raw materials (L. dorsi muscle) and water. The lean meat and brine were shortly mixed (10 s) at 2000 RPM before adding the ingredient under investigation (Table 1) to the Grindomix GM200 chopper (Retsch GmbH, Haan, Germany). The batter was further ground for approximately $5 \mathrm{~min}$ at $3500 \mathrm{RPM}$ to a temperature of $12{ }^{\circ} \mathrm{C}$.

After chopping, part of the meat batter was used directly to map dynamic viscoelastic properties (Section 2.3) and water binding parameters (Section 2.5). The residual meat batter was filled in 2 aluminum cans and heated for $90 \mathrm{~min}$ at $76^{\circ} \mathrm{C}$ in a Rational ClimaPlus Combi oven (Rational Belgium SA, Zwijndrecht, Belgium), which corresponds to an industrial pasteurization process. Afterwards the cans were stored in a cool cell at $3{ }^{\circ} \mathrm{C}$. Model 
systems were analyzed 5-6 days after processing with respect to cooking loss (Section 2.6), $\mathrm{pH}$ (Section 2.8), and textural properties (TPA, Section 2.9). Syneresis of the model systems was determined after 3 weeks of cold storage (Section 2.7).

The formulation of the FLM consisted of liver $(15 \mathrm{~g} / 100 \mathrm{~g})$, pork back fat $(50 \mathrm{~g} / 100 \mathrm{~g})$, and broth obtained by scalding the back fat $(35 \mathrm{~g} / 100 \mathrm{~g})$. It was processed by first separately prechopping the raw liver for $8 \mathrm{~min}$ at 3500 RPM in a Stephan UM12 vertical cutter-mixer (Stephan Machinery $\mathrm{GmbH}$, Hameln, Germany). The liver batter was stored at $4{ }^{\circ} \mathrm{C}$ until further processing. The back fat was scalded in boiling water during $20 \mathrm{~min}$. Afterwards, the scalded fat together with the broth were added to the bowl cutter and chopped at $3500 \mathrm{RPM}$ during $5 \mathrm{~min}$. Temperature of the obtained fat emulsion reached $50-51{ }^{\circ} \mathrm{C}$ at the end of chopping. The liver batter, nitrite curing salt $(1.6 \mathrm{~g} / 100 \mathrm{~g})$, and ingredient under investigation (Table 1) were added and mixed in the cutter during $3 \mathrm{~min}$ at $3500 \mathrm{RPM}$ and $80 \%$ of vacuum. Nitrite curing salt was calculated relative to the total mass of meat raw materials (liver and back fat) and broth. Part of the batter was immediately analyzed to determine dynamic viscoelastic properties (Section 2.3) and emulsion stability (Section 2.4). The remainder of the batter was subsequently filled into cans, heated, cooled, and stored in a cool cell until further analyses. Thermal processing conditions and analyses on finalized product (with the exception of syneresis) were the same as described for LMM.

Both recipes of the described model systems have a quite critical composition, meaning that they contain substantially more water and/or fat than regular meat products. These recipes were developed to induce poor product quality, allowing us to measure the effect of the different ingredients and compare them more easily.

\subsection{Dynamic Viscoelastic Properties}

Rheological measurements of both raw LMM and FLM batters were executed using an AR2000ex stress-controlled rheometer (TA Instruments, New Castle, DE, USA) equipped with a 40-mm parallel plate. The upper and lower plate were crosshatched to prevent slippage of the samples. The gap between the plates was set at $1000 \mu \mathrm{m}$. The AR2000ex was equipped with a Peltier temperature control system and upper heated plate (TA Instruments) to control the sample temperatures precisely.

Stress sweeps were executed at a temperature of $14{ }^{\circ} \mathrm{C}$ and $40{ }^{\circ} \mathrm{C}$ for LMM and FLM system, respectively. Oscillation stress was increased between 0.1 and $1000 \mathrm{~Pa}$ at constant frequency of $1 \mathrm{~Hz}$ to determine the linear viscoelastic region (LVR). The 'storage' and 'loss' modulus $\left(G^{\prime}\right.$, measurement of elastic characteristics and $G^{\prime \prime}$, measurement of viscous characteristics respectively) were directly obtained from the Rheology Advantage Data Analysis, v. 5.7.0 software (TA Instruments, New Castle, DE, USA). The LVR represents the stress range within which both $G^{\prime}$ and $G^{\prime \prime}$ are independent of the imposed stress amplitude and is determined according to Glorieux et al. [14]. The length of the LVR and the constant value of $\mathrm{G}^{\prime}$ within the LVR of both LMM (LVR-LMM, G'-LMM) and FLM (LVR-FLM, $G^{\prime}-F L M$ ) are expressed logarithmically and used in the cluster analysis (Section 2.10).

Temperature ramps and time sweeps were executed to examine structural changes of both LMM and FLM batters during heating and sequential cooling. The applied temperature profile represents the manufacturing process of industrially processed lean and fatty (emulsified) meat products. The following profile was applied: (1) heating from $14{ }^{\circ} \mathrm{C}$ and $40^{\circ} \mathrm{C}$ for LMM and FLM, respectively, to $76^{\circ} \mathrm{C}$ at a constant heating rate of $2{ }^{\circ} \mathrm{C} / \mathrm{min}$; (2) isothermal time sweep at $76{ }^{\circ} \mathrm{C}$ for $3 \mathrm{~min}$; (3) cooling from $76{ }^{\circ} \mathrm{C}$ to $14{ }^{\circ} \mathrm{C}$ at a constant cooling rate of $2{ }^{\circ} \mathrm{C} / \mathrm{min}$; (4) isothermal time sweep at $14{ }^{\circ} \mathrm{C}$ for $10 \mathrm{~min}$ (only for FLM). The entire process is illustrated in Figure 1, in which $\mathrm{G}^{\prime}$-values of interest regarding possible influence of added functional ingredients in both model systems are explained. These parameters were expressed logarithmically and used in the cluster analysis (Section 2.10). Oscillation measurements during the entire process were performed at a fixed frequency of $1 \mathrm{~Hz}$ and a constant strain of 0.010 for FLM and 0.025 for the LMM (within the LVR). Rheological measurements were executed in duplo for each experimental run regarding 
LMM batters, while for FLM, they were performed in singular due to instability of the freshly produced batter.

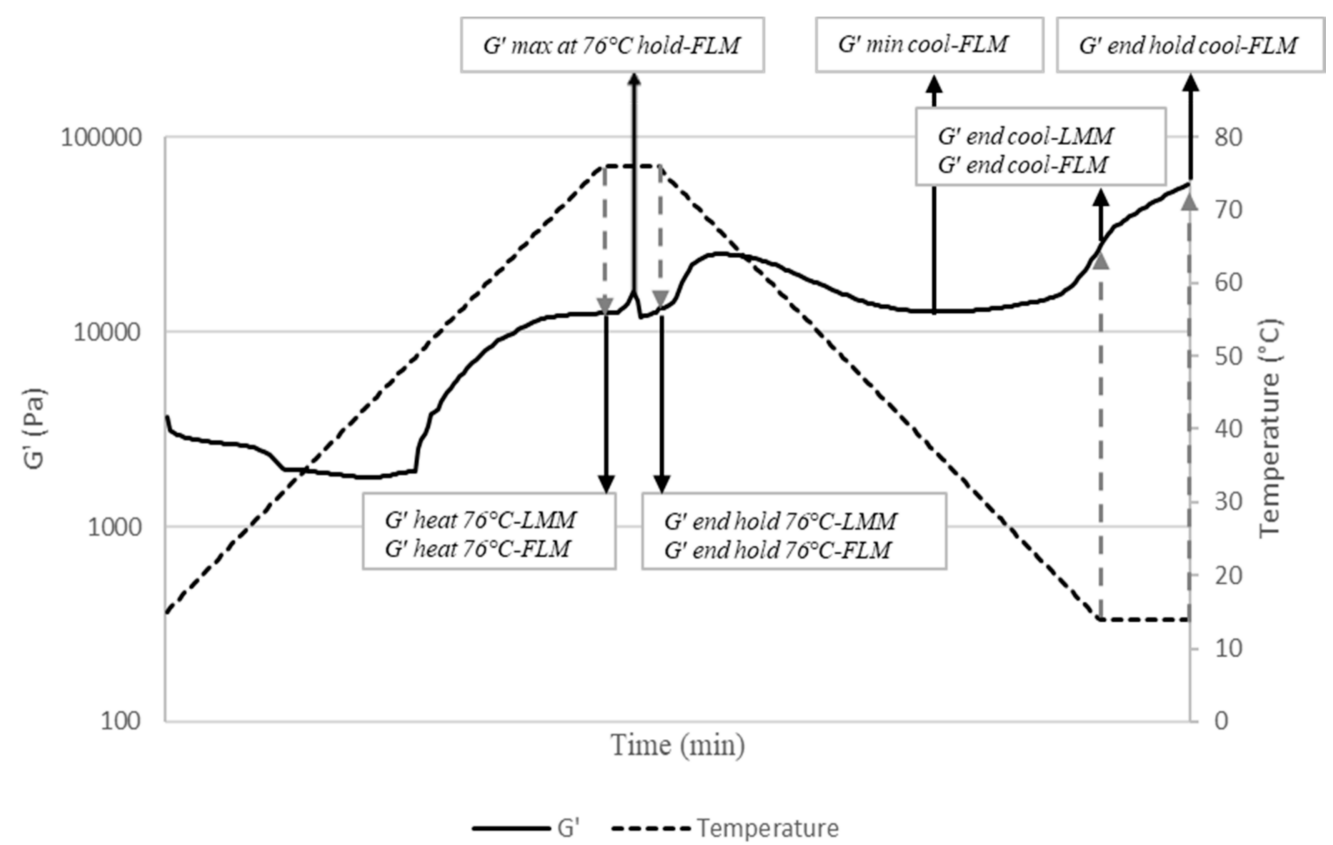

Figure 1. Rheological measurement, composed of a concatenation of temperature ramps and time sweeps, representing thermal process simulation of both LMM and FLM. Simulation starting temperatures are $14{ }^{\circ} \mathrm{C}$ and $40{ }^{\circ} \mathrm{C}$ for LMM and FLM, respectively. Second time sweep step at $14{ }^{\circ} \mathrm{C}$ is only executed for FLM. Values of $\mathrm{G}^{\prime}$ derived from graph and used as parameters in cluster analysis include: $G^{\prime}$ heat $76^{\circ} \mathrm{C}-L M M$ and $G^{\prime}$ heat $76^{\circ} \mathrm{C}-F L M$ referring to $\mathrm{G}^{\prime}$ at end of first temperature ramp $\left(76{ }^{\circ} \mathrm{C}\right)$ for both model systems; $G^{\prime} \max$ at $76^{\circ} \mathrm{C}$ hold-FLM referring to maximum measured value of $\mathrm{G}^{\prime}$ during first time sweep $\left(76^{\circ} \mathrm{C}\right)$ of FLM; $G^{\prime}$ end hold $76^{\circ} \mathrm{C}-L M M$ and $G^{\prime}$ end hold $76^{\circ} \mathrm{C}-F L M$ referring to $\mathrm{G}^{\prime}$ at end of first time sweep $\left(76^{\circ} \mathrm{C}\right)$ for both model systems; $G^{\prime}$ min cool-FLM referring to minimum value of $\mathrm{G}^{\prime}$ during second temperature ramp of FLM; $G^{\prime}$ end cool-LMM and $G^{\prime}$ end cool-FLM referring to $\mathrm{G}^{\prime}$ at end of second temperature ramp $\left(14{ }^{\circ} \mathrm{C}\right)$ for both model systems; $G^{\prime}$ end hold cool-FLM referring to $\mathrm{G}^{\prime}$ at end of second time sweep $\left(14^{\circ} \mathrm{C}\right)$ of FLM.

\subsection{Emulsion Stability}

Emulsion stability of FLM was determined immediately after batter preparation according to Glorieux, Goemaere, Steen and Fraeye [14] with slight modifications. Summarized, emulsion stability is expressed as drip loss upon heating $\left(30 \mathrm{~min}, 75^{\circ} \mathrm{C}\right)$ and centrifugation at $4234 \times g$ by means of a Universal $320 \mathrm{R}$ centrifuge (Andreas Hettich $\mathrm{GmbH}$ \& Co. KG, Tuttlingen, Germany) at $25^{\circ} \mathrm{C}$ for $3 \mathrm{~min}$ of a preweighed amount of raw batter. The percentage of total expressible fluid (TEF-FLM) was expressed as follows:

$$
\text { TEF }-F L M(\%)=\frac{\text { drip loss }}{\text { initial weight sample }} \times 100
$$

In addition, the relative amount of water next to the fat in the drip was determined. Therefore, drip loss after centrifugation was collected and weighed before and after drying in a Typ U 40 oven (Memmert, Schwabach, Germany) for $24 \mathrm{~h}$. The relative amount of water in the drip loss was expressed as follows:

Relative amount of $\mathrm{H}_{2} \mathrm{O}$ in drip $-F L M(\%)=\frac{\text { drip loss before drying }- \text { drip loss after drying }}{\text { drip loss before drying }} \times 100$ 
TEF-FLM and Relative amount of $\mathrm{H}_{2} \mathrm{O}$ in drip-FLM were determined in triplicate for each experimental run and used as parameters in the cluster analysis.

\subsection{Drip Loss}

The drip loss of the raw batter of LMM was measured immediately after batter preparation (Drip loss cold-LMM). The determination was executed in duplo for each experimental run by centrifuging $30 \mathrm{~g}$ of meat batter at $9526 \times g(9000 \mathrm{rpm})$ for $5 \mathrm{~min}$ at $25^{\circ} \mathrm{C}$, after which the separated fluid was weighed. Drip loss cold-LMM was expressed as follows:

$$
\text { Drip loss cold }-\operatorname{LMM}(\%)=\frac{\text { drip loss }}{\text { initial weight sample }} \times 100
$$

Determination of the drip loss of the batter of LMM upon heating (Drip loss hot-LMM) is similar to the cold procedure, albeit that before centrifugation at $470 \times g(2000 \mathrm{rpm})$ for $1 \mathrm{~min}$ at $25^{\circ} \mathrm{C}$ the samples were heated at $75^{\circ} \mathrm{C}$ for $30 \mathrm{~min}$ in a $\mathrm{KK} 2800$ smoke-air cooker (Kerres Anlagen systeme $\mathrm{GmbH}$, Backnang, Germany). Drip loss hot-LMM was determined in triplicate for each experimental run and expressed as follows:

$$
\text { Drip loss hot }-\operatorname{LMM}(\%)=\frac{\text { drip loss }}{\text { initial weight sample }} \times 100
$$

Drip loss cold-LMM and Drip loss hot-LMM were used as parameters in the cluster analysis.

\subsection{Cooking Loss}

Cooking loss of LMM (CL-LMM) was determined in duplo for each experimental run according to Perez-Santaescolastica et al. [15]. Cooking loss was calculated as follows and applied as a parameter in the cluster analysis:

$$
C L-\operatorname{LMM}(\%)=\frac{\text { drip loss }}{\text { initial weight sample }} \times 100
$$

\subsection{Syneresis}

LMM was sliced and MAP packed $\left(70 \% \mathrm{~N}_{2}\right.$ and $\left.30 \% \mathrm{CO}_{2}\right)$ in plastic trays. The trays were stored upright under an angle of $45^{\circ}$ in a cool cell at $3{ }^{\circ} \mathrm{C}$. After 3 weeks of storage, the drip loss was collected and used as a measurement for the syneresis of the sample. Syneresis-LMM was determined in duplo for each experimental run and expressed as follows:

$$
\text { Syneresis }-\operatorname{LMM}(\%)=\frac{\text { drip loss }}{\text { initial weight sample }} \times 100
$$

\section{8. $p H$}

$\mathrm{pH}$ of the model systems was measured as described in Glorieux, Goemaere, Steen and Fraeye [14]. A total of 4 and $6 \mathrm{pH}$-values were obtained for each experimental run regarding LMM and FLM, respectively. $p H-L M M$ and $p H-F L M$ were used as parameters in the cluster analysis.

\subsection{Texture}

Hardness of the model systems was determined using a Lloyd Texture Analyzer Model LF plus (Lloyd Instruments Ltd, Bognor Regis, UK) and expressed as the maximum force (N) to penetrate the sample, as described in Perez-Santaescolastica, Goemaere, Hanskens, Lorenzo and Fraeye [15]. A total of 4 and 9 hardness values were obtained for each experimental run regarding LMM and FLM, respectively. Hardness-LMM and HardnessFLM were used as parameters in the cluster analysis. 


\subsection{Cluster Analysis}

To cluster all ingredients with the given concentration (high/low), a hierarchical cluster analysis was performed based on the 23 above-described quality parameters. Mean values of each parameter per ingredient $x$ dosage combination were expressed relative to their corresponding average blank value by dividing both and used for further statistical processing. To define the clusters, Ward's minimum variance method was used [16] Decision on the number of clusters was based on the Cubic Clustering Criterion (CCC) that is proposed in the JMP Pro 14 software.

All statistical analyses were performed in JMP Pro 14 (SAS Institute, Cary, NC, USA).

\section{Results}

\subsection{Overview Hierarchical Clustering}

Figure 2 reveals the hierarchical clustering of the tested ingredient $x$ dosage combinations. To construct the clustering, all 23 measured parameters on LMM and FLM were considered. Five main clusters, indicated by different colors, can be distinguished based on the CCC. Each cluster groups ingredient $x$ dosage combinations showing similar and unique behavior. In the paragraphs below, each cluster is described, and explanations are formulated to comprehend the differences between them. The green cluster containing the blank sample is discussed first and set as a reference to evaluate the others.

\subsection{Green Reference Cluster}

The green cluster includes the blank (reference) to which no ingredients were added. Hence, ingredient $x$ dosage combinations in the green cluster represent samples which have limited impact on the parameters measured compared to the blank sample. Of the five clusters identified, the green cluster groups the highest amount of ingredients, mainly ingredients at LD. The LD of each ingredient class is established, as mentioned before, based upon literature and available product sheets and corresponds approximately to the minimum dosage needed to improve product quality to some extent. As a consequence, the impact of LD ingredients on parameters measured is rather small compared to the blank.

Closest to the blank sample are mainly collagen-derived proteins and plant proteins at LD. The contribution of gelatins to water binding in heated meat products is rather limited mainly due to their lack of gelling capacity at high temperature. During heating, gelatin solubilizes in the watery phase [17] and can migrate out of the product together with the cooking loss. Since the gelatin network is thermo-reversible $[18,19]$, it can partially reappear during cooling outside the product matrix as gel deposits. Its contribution to water binding and texture/structure of standard heated meat products is therefore rather limited.

In general, plant proteins have less pronounced functional properties compared to that of animal proteins in meat products. Moreover, an effective replacement of animal proteins requires certain technological innovations. New extraction and drying technologies are proposed to ameliorate functional characteristics of plant proteins such as pea protein $[1,18]$. Adding them at LD apparently often resulted in a limited effect on the parameters measured. 

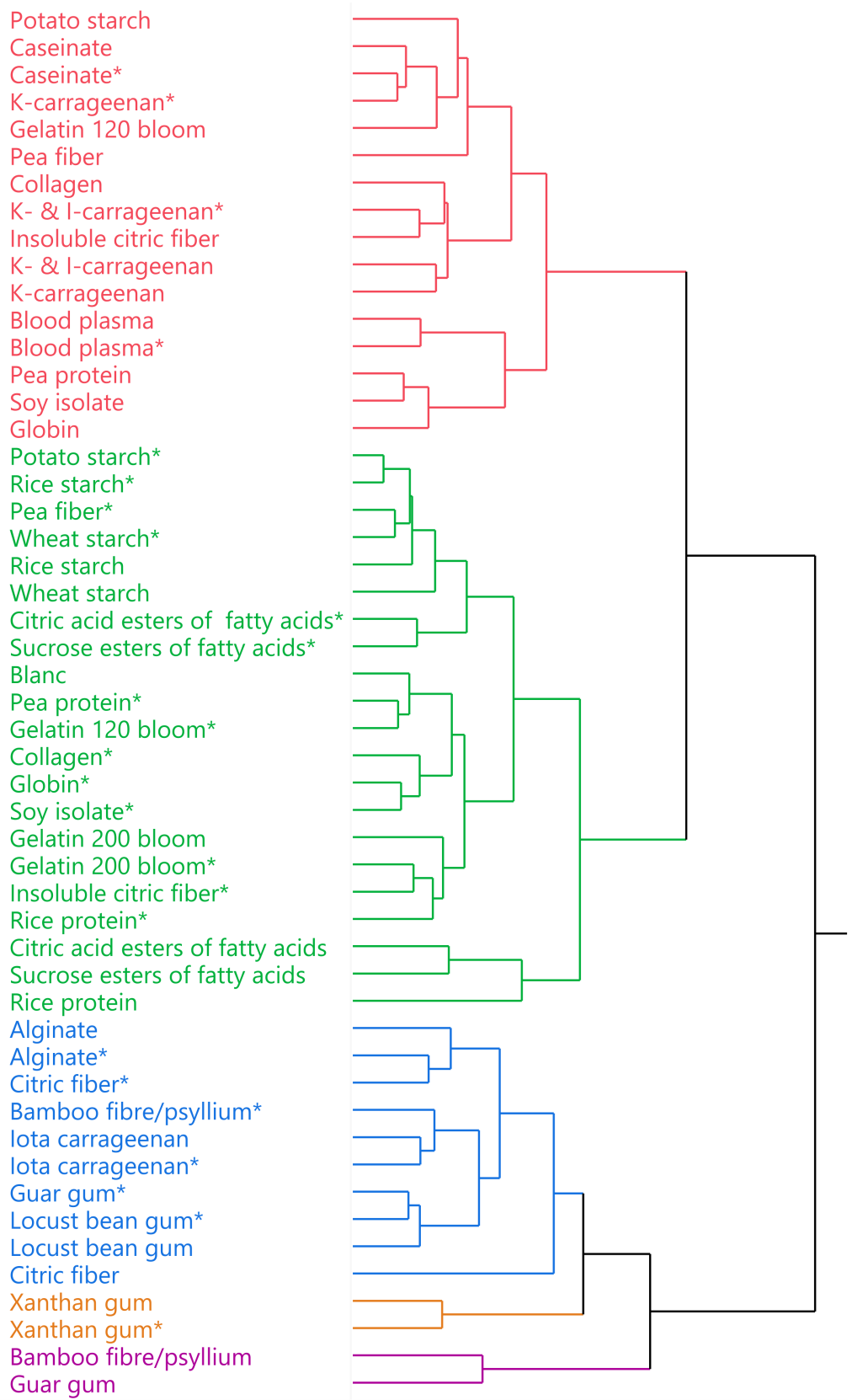

Figure 2. Dendrogram based on hierarchical cluster analysis of 25 screened ingredients at 2 dosages. Ingredient $x$ dosage combinations occurring in same color have similar properties and belong to same cluster. ' ${ }^{* \prime}$ means ingredient is tested at low dosage. Dosage is product class-dependent, as indicated in Table 1.

Somewhat further away from the blank sample are starches and emulsifiers. The appearance of pea fiber in that group can be easily explained due to the relatively high amount of starch in the composition of the ingredient, according to the manufacturer (not shown). All starches screened in the experiment are (functional) native starches. In general, the functionality of native starches is rather restricted compared to chemically modified starches, which could explain their occurrence in the green cluster. Nowadays more and more starch producers have found innovative solutions to create 'native functional' starches by using physical processes with comparable properties to chemically modified ones [1,9]. The presumable contribution of emulsifiers sensu stricto to product characteristics, most likely fat stabilization, is only possible in fat-containing products. In the LMM, they do not exert any function at all. This may partly explain the presence of emulsifiers in the green 
cluster. Emulsifiers and rice protein at HD are at the edge of the green cluster away from the blank. This can be explained by their negative impact on measured product parameters. Rheological thermal process simulations revealed interference of these ingredients with the formation of the liver gel network during heating (low $G^{\prime}$ heat $76{ }^{\circ} \mathrm{C}-F L M$ ). As a consequence, an inferior stabilization of fat, expressed as a high increase of TEF-FLM, occurred. In case of emulsifiers, these phenomena can be explained through the different theories of fat stabilization in meat batters. The first theory states that stabilization of fat results from the formation of an interfacial protein film (IPF) around the fat globule, while the second one claims that fat globules are physically entrapped within the protein matrix [13]. Meat emulsions, like the FLM, are characterized by solubilized liver proteins encapsulating the fat within the matrix [20]. During heating, the emulsion is stabilized by the formation of protein cross-links between proteins in the IPF and the matrix proteins. In contrast, when nonprotein emulsifiers such as mono- and diglycerides are added, these emulsifiers can adsorb at the surface of the fat globules in preference to the liver proteins and cause a reduction in protein-lipid interactions. In this case, crosslinking of the IPF to the protein matrix is usually absent, and as a consequence, the continuous protein network may be altered, leading to an increase in fat loss [13]. The negative impact of rice protein on formation of the liver protein network and subsequent increase in drip loss can possibly be attributed to its damaging and weakening effect on the gel-forming ability of the liver proteins. Gu et al. [21] observed similar behavior when rice proteins were added to silver carp surimi gels. They presumed this was caused by impact of the rice proteins on the cross-linking abilities between myofibrillar proteins, consequently disrupting the fish gel matrix. Lin et al. [22] also noticed disruption of the microstructure of a myofibrillar protein gel upon addition of a mixture of rice and peanut protein isolate.

\subsection{Red Cluster}

Many ingredients in the red cluster are only included at HD, while their LD counterparts are located in the green 'reference' cluster, meaning that for these ingredients higher dosages usually have greater impact on the parameters measured. Figure 3 a shows for each parameter the mean value over all ingredient $x$ dosage combinations included in the red cluster compared to that of the green 'reference' cluster. In general, there is an improvement of all measured parameters for both model systems. Water-binding parameters of LMM show a decrease in cooking loss and drip loss of the raw and heated meat batter, and a small reduction of syneresis. Furthermore, hardness and rheological parameters of LMM batter before and during heating and subsequent cooling illustrate higher values indicating a firmer product structure. Similar conclusions, such as smaller drip losses and increased product structure, can be drawn from FLM. This cluster is further defined by ingredients which generally increase product $\mathrm{pH}$ to a small extent. Hereby, $\mathrm{pH}$ shifts away from the iso-electric point of the myofibrillar proteins, creating a greater net charge and repulsion between proteins [14]. It could also contribute to the improved water binding capacities of both model systems, but this is doubtful due to the rather small increase of $\mathrm{pH}$.

The red cluster is populated with several proteins and more specifically animal proteins with good warm gelling and emulsifying properties such as globin, blood plasma, and caseinate [2,3,23-27]. The latter two already alter product quality at LD. Plant proteins such as soy isolate and pea protein can establish similar behavior, but only at HD. Another group of ingredients observed in the red cluster are (combinations of) $\mathrm{k}$-carrageenans, both at LD and HD. $\mathrm{k}$-carrageenan is widely used in the meat industry for its gelling properties and corresponding water-binding and structure-improving capabilities [28-31]. Several authors [28,32] stated that increased gel strength is probably not caused by molecular interaction between carrageenan and proteins. Verbeken et al. [33] claim this is probably due to the presence of carrageenans in the interstitial spaces of the protein network, where they form gel fragments upon cooling and therefore retain water. Impact of $\mathrm{k}$-carrageenan on hardness is higher compared to that of ı-carrageenan [34]. This can possibly be related to the fact that $\mathrm{k}$-carrageenan can form brittle gels, while $\mathrm{t}$-carrageenan forms elastic 
gels $[28,31]$. The different behavior between carrageenan types may also explain the difference in cluster classification for both ingredients. The behavior of (combinations of) $\kappa$-carrageenans is similar to the above-described protein performance and exactly what defines the red cluster. These findings contribute to the justification of the developed meat model systems as a screening instrument for functional ingredients and the choice of cluster analysis as statistical tool for data processing.
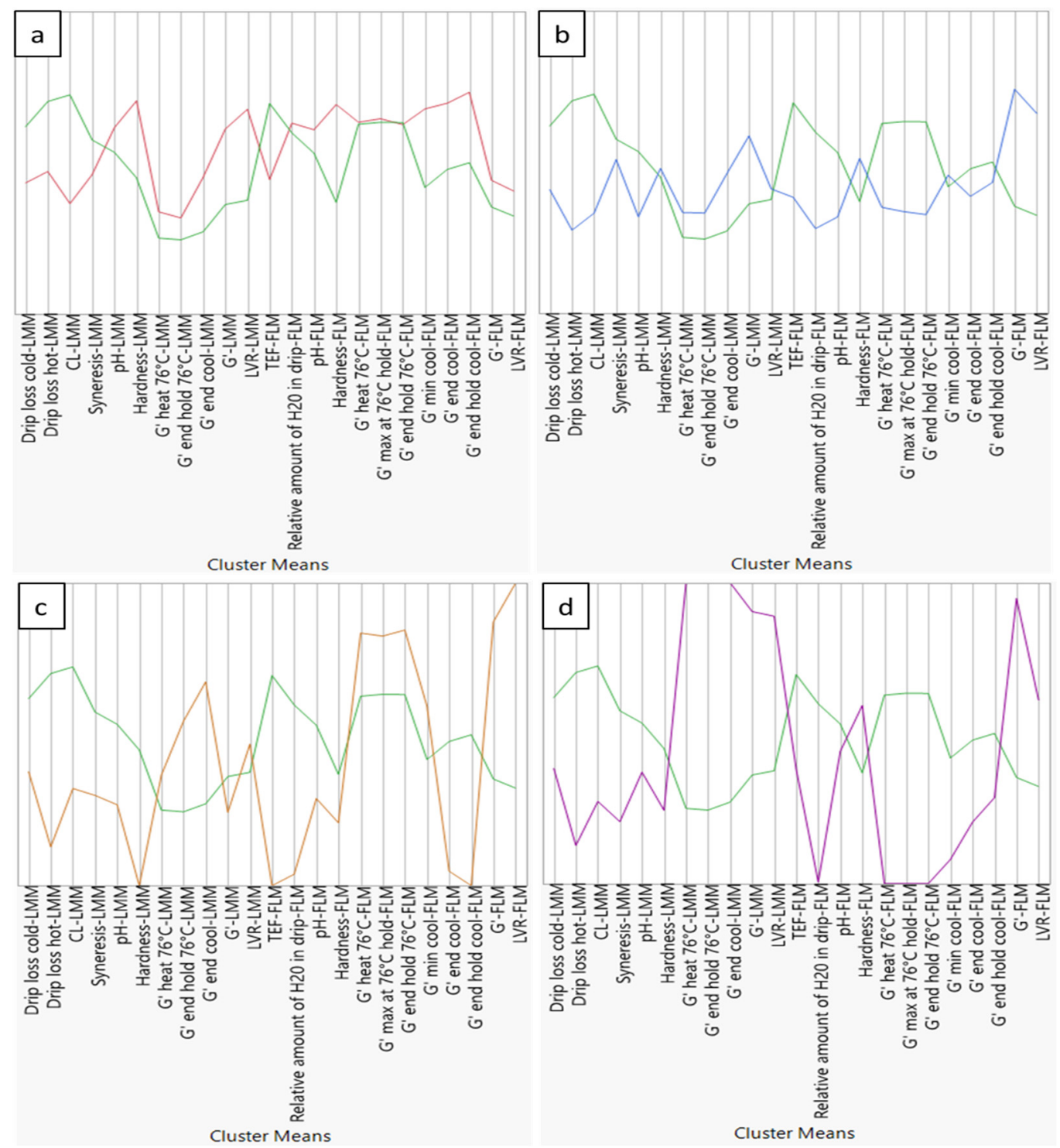

Figure 3. Parallel coordinates plots to provide an overview of 5 cluster means consisting out of 23 quality characteristics determined through developed lean meat model and fatty liver-based model. (a) Represents comparison of the 'green reference cluster' means vs. red cluster means; (b) represents comparison of 'green reference cluster' means vs. blue cluster means; (c) represents comparison of 'green reference cluster' means vs. orange cluster means, and (d) represents comparison of 'green reference cluster' means vs. purple cluster means. Explanation on used abbreviations can be found in Section 2 (Materials and Methods) and Figure 1. Axes range from two standard deviations above and below mean, where standard deviation and mean are computed for raw data.

Potato starch and pea fiber at HD also show similar behavior compared to proteins and carrageenans, most likely because starch gelatinization during heating results in inclusion of water and increase of product structure. Potato starch has some advantages compared to other native starches, such as low gelatinization temperature $\left(60-65^{\circ} \mathrm{C}\right)$, high water 
binding capacity, and high viscosity. The combination of these attributes makes it an attractive ingredient for meat processing [3].

\subsection{Blue Cluster}

The blue cluster mainly contains ingredients such as gums and fibers with a soluble component. Most of those ingredients are present in the cluster both at LD and HD, indicating that small dosages already influence product quality. On the other hand, ingredients at HD have a more pronounced effect on certain parameters (individual results not shown) but this does not result into their classification in another cluster, suggesting that the impact of increased dosage on product parameters is rather limited. Figure $3 b$ shows the comparison between cluster means of the green 'reference' and blue cluster. The unique character of this cluster is first determined by a strong water binding capacity. This was noticed in both LMM and FLM. Additionally, a shift in composition of the drip loss of FLM can be observed. The relative amount of water in the drip is substantially lower compared to that of the green 'reference' or red cluster. This is probably related to the rather strong water binding capacity and increase of batter viscosity caused by the 'blue cluster ingredients'. The impact on structure of the raw and heated batter, especially of FLM, differs substantially from the green and red cluster. Structure $\left(G^{\prime}-F L M\right)$ and structure strength ( $L V R-F L M)$ of the raw batter are increased, while on the other hand, a rather strong negative impact on the formation of the liver network during heating is observed $\left(G^{\prime}\right.$ max at $76{ }^{\circ} \mathrm{C}$ hold-FLM).

Gums and fibers with a large proportion of soluble components are characterized by a thickening or weak gelling character, and therefore greatly improve water-binding capacity. These properties result from an equilibrium between water-gum interactions and intermolecular forces (i.e., hydrogen, hydrophobic and electrostatic bonds), which leads to the formation of aggregates or 3D matrix structures [1,12]. According to Tarté [4], fibers containing a higher level of soluble fibers, as was the case with the examined citric fiber and mixture of bamboo fiber and psyllium (due to the latter) [35,36], can boost water absorption, but tend not to have the oil/fat-binding capability of the higher insoluble fraction varieties. This could possibly explain the shift in composition of the drip loss for FLM.

The impact on structural parameters and protein network formation by ingredients in the blue cluster is described by several other authors. Whiting [37] stated that addition of guar could possibly disrupt the protein-protein gel network, which negatively affected gel strength as seen for FLM. Ramírez et al. [38] indicated a decrease in shear stress when locust bean gum is added to surimi gels. On the other hand Montero et al. [39] noticed an increase in breaking deformation and work of penetration when locust bean gum is added to fish proteins gels. They attributed this to the water-holding of the gum resulting in a more deformable gel. The same authors observed changes in myofibrillar gel flexibility and its breaking deformation by use of $\mathrm{\iota}$-carrageenan. In the current research, the addition of $\mathrm{t}$-carrageenan interfered with protein network formation, as seen by thermal processing simulation in FLM $\left(G^{\prime} \max\right.$ at $76^{\circ} \mathrm{C}$ hold-FLM). Several authors investigated the impact of alginate on structure and texture of meat products and protein gels. Sarteshnizi, Hosseini, Mousavi Khaneghah and Narges [28] suggested that alginate could change the physical state of proteins and affect texture of meat products. Furthermore Xiong and Blanchard [40] found a reduction in the gelling capacity of suspensions containing several combinations of salt-soluble proteins and alginate. They claim this could possibly be explained through interference in the protein network at gelling point. It is also probable that alginate has some influence on the electrostatic bonding, leading to a lower gel firmness in the final gelled product. The latter was especially noticeable in FLM as $G^{\prime}$ end cool-FLM was much lower compared to that of the blank.

\subsection{Orange Cluster}

This cluster is solely occupied by xanthan at both dosages. As seen in Figure 3c, the orange cluster represents a very high water-binding capacity for both model systems, an 
atypical impact on structure formation observed during thermal process simulation, and a detrimental impact on product hardness compared to that of the green 'reference' cluster. The unique property of xanthan is the ability to increase viscosity of a liquid already at very low concentrations [30,41]. Sánchez, Bartholomai and Pilosof [12] concluded xanthan is very good at holding water within the meat matrix and stabilizing emulsions. Montero, Hurtado and Pérez-Mateos [39] noticed a great impact of xanthan addition on the structure of fish gels; it led to a decrease in gel forming capacity of the myofibrillar proteins as seen in the current research $\left(G^{\prime} \max\right.$ at $76^{\circ} \mathrm{C}$ hold-LMM and $\left.F L M\right)$. According to the authors, this was related to the presence of xanthan in the interstitial spaces of the matrix, where its high molecular weight probably hindered formation of the protein matrix. Also, its construction of large cavities in the network could be linked to the impact on structure. On the other hand Ramírez, Barrera, Morales and Vázquez [38] attributed the negative effects of xanthan to its anionic nature. Myofibrillar proteins are negatively charged at $\mathrm{pH}$ values above their isoelectric point, which is generally the case in meat and fish products, causing a repulsive effect with xanthan. This antagonistic effect weakens the protein network.

\subsection{Purple Cluster}

The purple cluster contains only two ingredient $x$ dosage combinations: guar and the mixture bamboo and psyllium both at HD. The main reason only few ingredients are present in this cluster is, like in the orange cluster, the rather extreme behavior of the samples as seen in Figure 3d. Especially the evolution of $G^{\prime}$ during thermal processing differed substantially compared to other ingredient $\mathrm{x}$ dosage combinations, as observed through extreme high and low values of $G^{\prime}$ end hold $76^{\circ} \mathrm{C}$ - for LMM and FLM, respectively. Despite the impact on product structure formation during processing, hardness of both LMM and FLM is not greatly affected, in contrast to xanthan (orange cluster). Although both orange and purple clusters exhibit ingredient $\mathrm{x}$ dosage combinations with divergent behavior, the developed model systems can still distinguish them. The intrinsic characteristics of psyllium, such as its extremely high water-binding and gel properties could explain the position of this ingredient in the purple cluster [4].

\section{Conclusions}

The developed toolbox consisting of a lean meat and fatty liver-based model system was a trustworthy measuring instrument to obtain standardized and comparable data concerning intrinsic ingredient functionalities. Hierarchical cluster analysis could create an efficient overview of 'ingredient $x$ dosage combinations' based upon similar behavior, rather than product class, while maintaining a great distinctive power. It revealed 5 main ingredient clusters, each with their own unique characteristics. This new approach will help the meat industry and its partners in making the right choice of ingredient for specific meat applications based on scientific, standardized, and comparable data. Ingredient manufacturers and suppliers can also call on this screening tool to reveal the intrinsic characteristics of newly developed ingredients and compare them with what is available in the market. In future work, the obtained knowledge on model system level will be translated to several types of industrial meat products. The parameters measured in the model systems will be linked to quality characteristics of meat products on industrial scale.

Author Contributions: Conceptualization, O.G. and I.F.; formal analysis, B.D.K.; funding acquisition, I.F.; investigation, O.G., J.H., Q.M. and C.P.S.; methodology, O.G. and I.F.; project administration, I.F.; resources, I.F.; supervision, I.F.; validation, J.H., Q.M. and C.P.S.; visualization, O.G.; writingoriginal draft, O.G.; writing—review \& editing, B.D.K., J.H., Q.M., C.P.S. and I.F. All authors have read and agreed to the published version of the manuscript.

Funding: This research was funded by 'Agentschap Innoveren en Ondernemen' (Vlaio) and the support from the Flemish meat industry and its suppliers in the TETRA project FUNC-I-MEAT (HBC.2017.0047). 
Conflicts of Interest: The authors declare no conflict of interest. The funders had no role in the design of the study; in the collection, analysis, or interpretation of data; in the writing of the manuscript, or in the decision to publish the results.

\section{References}

1. Balestra, F.; Petracci, M. Technofunctional Ingredients for Meat Products: Current Challenges. In Sustainable Meat Production and Processing; Galanakis, C.M., Ed.; Academic Press: Cambridge, MA, USA, 2019; pp. 45-68. [CrossRef]

2. Toldrà, M.; Lynch, S.A.; Couture, R.; Álvarez, C. Blood Proteins as Functional Ingredients. In Sustainable Meat Production and Processing; Galanakis, C.M., Ed.; Academic Press: Cambridge, MA, USA, 2019; pp. 85-101. [CrossRef]

3. Petracci, M.; Bianchi, M.; Mudalal, S.; Cavani, C. Functional ingredients for poultry meat products. Trends Food Sci. Technol. 2013, 33, 27-39. [CrossRef]

4. Tarté, R. Ingredients in Meat Products: Properties, Functionality and Applications, 1st ed.; Tarté, R., Ed.; Springer: New York, NY, USA, 2009. [CrossRef]

5. Thangavelu, K.P.; Kerry, J.P.; Tiwari, B.K.; McDonnell, C.K. Novel processing technologies and ingredient strategies for the reduction of phosphate additives in processed meat. Trends Food Sci. Technol. 2019, 94, 43-53. [CrossRef]

6. Weiss, J.; Gibis, M.; Schuh, V.; Salminen, H. Advances in ingredient and processing systems for meat and meat products. Meat Sci. 2010, 86, 196-213. [CrossRef] [PubMed]

7. Skrede, G. Comparison of various types of starch when used in meat sausages. Meat Sci. 1989, 25, 21-36. [CrossRef]

8. Pietrasik, Z.; Janz, J.A.M. Utilization of pea flour, starch-rich and fiber-rich fractions in low fat bologna. Food Res. Int. 2010, 43 , 602-608. [CrossRef]

9. Zhang, L.; Barbut, S. Effects of regular and modified starches on cooked pale, soft, and exudative; normal; and dry, firm, and dark breast meat batters. Poult. Sci. 2005, 84, 789-796. [CrossRef]

10. Youssef, M.K.; Barbut, S. Effects of two types of soy protein isolates, native and preheated whey protein isolates on emulsified meat batters prepared at different protein levels. Meat Sci. 2011, 87, 54-60. [CrossRef]

11. Egbert, W.R.; Payne, C.T. Plant Proteins. In Ingredients in Meat Products: Properties, Functionality and Applications; Tarté, R., Ed.; Springer: New York, NY, USA, 2009; pp. 111-129. [CrossRef]

12. Sánchez, V.E.; Bartholomai, G.B.; Pilosof, A.M.R. Rheological Properties of Food Gums as related to their water binding capacity and to soy protein interaction. LWT Food Sci. Technol. 1995, 28, 380-385. [CrossRef]

13. Gordon, A.; Barbut, S.; Schmidt, G. Mechanisms of meat batter stabilization: A review. Crit. Rev. Food Sci. Nutr. 1992, 32, $299-332$. [CrossRef]

14. Glorieux, S.; Goemaere, O.; Steen, L.; Fraeye, I. Phosphate Reduction in Emulsified Meat Products: Impact of Phosphate Type and Dosage on Quality Characteristics. Food Technol. Biotechnol. 2017, 55, 390-397. [CrossRef]

15. Perez-Santaescolastica, C.; Goemaere, O.; Hanskens, J.; Lorenzo, J.M.; Fraeye, I. Effect of stabiliser classes (animal proteins, vegetable proteins, starches, hydrocolloids and dietary fibre) on the physicochemical properties of a model lean meat product. Int. J. Food Sci. Tech. 2020, 55, 970-977. [CrossRef]

16. Johnson, R.A.; Wichern, D.W. Applied Multivariate Statistical Analysis, 6th ed.; Prentice Hall: Hoboken, NJ, USA, 2007.

17. Sultana, S.; Ali, M.E.; Ahamad, M.N.U. Gelatine, collagen, and single cell proteins as a natural and newly emerging food ingredients. In Preparation and Processing of Religious and Cultural Foods; Ali, M.E., Nizar, N.N.A., Eds.; Woodhead Publishing: Cambridge, UK, 2018; pp. 215-239. [CrossRef]

18. Phillips, G.; Williams, P. Handbook of Hydrocolloids, 2nd ed.; Woodhead Publishing: Cambridge, UK, 2009 ; pp. 1-924.

19. Gómez-Guillén, M.C.; Giménez, B.; López-Caballero, M.E.; Montero, M.P. Functional and bioactive properties of collagen and gelatin from alternative sources: A review. Food Hydrocoll. 2011, 25, 1813-1827. [CrossRef]

20. Schilling, M.W. Emulsifier Applications in Meat Products. In Food Emulsifiers and Their Applications; Hasenhuettl, G.L., Hartel, R.W., Eds.; Springer: New York, NY, USA, 2019; pp. 347-377. [CrossRef]

21. Gu, R.; Xiao, X.; Sun, J.; Shi, L.; Yang, H. Effects of rice residue on physicochemical properties of silver carp surimi gels. Int. J. Food Prop. 2018, 21, 1743-1754. [CrossRef]

22. Lin, D.; Zhang, L.; Li, R.; Zheng, B.; Rea, M.C.; Miao, S. Effect of plant protein mixtures on the microstructure and rheological properties of myofibrillar protein gel derived from red sea bream (Pagrosomus major). Food Hydrocoll. 2019, 96, 537-545. [CrossRef]

23. Prabhu, G.A. Utilizing functional meat-based proteins in processed meat applications. In Proceedings of the 55th Annual Reciprocal Meat Conference, Savoy, IL, USA, 29 July 2002; pp. 29-34.

24. O'Regan, J.; Ennis, M.P.; Mulvihill, D.M. Milk proteins. In Handbook of Hydrocolloids, 2nd ed.; Phillips, G.O., Williams, P.A., Eds.; Woodhead Publishing: Cambridge, UK, 2009; pp. 298-358. [CrossRef]

25. Lynch, S.A.; Mullen, A.M.; O’Neill, E.E.; García, C.Á. Harnessing the Potential of Blood Proteins as Functional Ingredients: A Review of the State of the Art in Blood Processing. Compr. Rev. Food Sci. Food Saf. 2017, 16, 330-344. [CrossRef] [PubMed]

26. Youssef, M.K.; Barbut, S. Effects of caseinate, whey and milk proteins on emulsified beef meat batters prepared with different protein levels. J. Muscle Foods 2010, 21, 785-800. [CrossRef]

27. Tarté, R. Meat-Derived Protein Ingredients. In Ingredients in Meat Products: Properties, Functionality and Applications; Tarté, R., Ed.; Springer: New York, NY, USA, 2009; pp. 145-171. [CrossRef] 
28. Sarteshnizi, R.; Hosseini, H.; Mousavi Khaneghah, A.; Narges, K. A review on application of hydrocolloids in meat and poultry products. Int. Food Res. J. 2015, 22, 872-887.

29. Ayadi, M.A.; Kechaou, A.; Makni, I.; Attia, H. Influence of carrageenan addition on turkey meat sausages properties. J. Food Eng. 2009, 93, 278-283. [CrossRef]

30. Lamkey, J.W. Nonstarch Hydrocolloids. In Ingredients in Meat Products: Properties, Functionality and Applications; Tarté, R., Ed.; Springer: New York, NY, USA, 2009; pp. 57-82. [CrossRef]

31. Imeson, A.P. Carrageenan and furcellaran. In Handbook of Hydrocolloids, 2nd ed.; Phillips, G.O., Williams, P.A., Eds.; Woodhead Publishing: Cambridge, UK, 2009; pp. 164-185. [CrossRef]

32. DeFreitas, Z.; Sebranek, J.G.; Olson, D.G.; Carr, J.M. Carrageenan Effects on Salt-Soluble Meat Proteins in Model Systems. J. Food Sci. 1997, 62, 539-543. [CrossRef]

33. Verbeken, D.; Neirinck, N.; Van Der Meeren, P.; Dewettinck, K. Influence of K-carrageenan on the thermal gelation of salt-soluble meat proteins. Meat Sci. 2005, 70, 161-166. [CrossRef] [PubMed]

34. Foegeding, E.A.; Ramsey, S.R. Rheological and Water-Holding Properties of Gelled Meat Batters Containing Iota Carrageenan, Kappa Carrageenan or Xanthan gum. J. Food Sci. 1987, 52, 549-553. [CrossRef]

35. Mehta, N.; Ahlawat, S.S.; Sharma, D.P.; Dabur, R.S. Novel trends in development of dietary fiber rich meat products-a critical review. J. Food Sci. Technol. 2015, 52, 633-647. [CrossRef]

36. Yegin, S.; Kopec, A.; Kitts, D.D.; Zawistowski, J. Dietary fiber: A functional food ingredient with physiological benefits. In Dietary Sugar, Salt and Fat in Human Health; Preuss, H.G., Bagchi, D., Eds.; Academic Press: Cambridge, MA, USA, 2020; pp. 531-555. [CrossRef]

37. Whiting, R.C. Addition of Phosphates, Proteins, and Gums to Reduced-Salt Frankfurter Batters. J. Food Sci. 1984, 49 , 1355-1357. [CrossRef]

38. Ramírez, J.A.; Barrera, M.; Morales, O.G.; Vázquez, M. Effect of xanthan and locust bean gums on the gelling properties of myofibrillar protein. Food Hydrocoll. 2002, 16, 11-16. [CrossRef]

39. Montero, P.; Hurtado, J.L.; Pérez-Mateos, M. Microstructural behaviour and gelling characteristics of myosystem protein gels interacting with hydrocolloids. Food Hydrocoll. 2000, 14, 455-461. [CrossRef]

40. Xiong, Y.L.; Blanchard, S.P. Viscoelastic Properties of Myofibrillar Protein-Polysaccharide Composite Gels. J. Food Sci. 1993, 58, 164-167. [CrossRef]

41. Demirci, Z.O.; Yılmaz, I.; Demirci, A. Effects of xanthan, guar, carrageenan and locust bean gum addition on physical, chemical and sensory properties of meatballs. J. Food Sci. Technol. 2014, 51, 936-942. [CrossRef] [PubMed] 